\author{
JIR̆Í SUBRT
}

\title{
VÝCHODISKA GIDDENSOVA PŘÍSTUPU K REKONSTRUKCI SOCIÁLNÍ TEORIE
}

\section{VŸVOJOVÉ ETAPY GIDDENSOVY TEORETICKÉ ČINNOSTI}

Málokterý ze soudobých sociologů je autorem tak ambiciozního, rozsáhlého a zároveň diskutovaného díla jako Anthony Giddens (nar. 1938 v Londýně). Studoval v Hullu (Yorkshire) a na London School of Economics. Jeho profesní dráha je spojena s Univerzitou Leicester (60. léta), dále pak s Univerzitou Cambridge, Univerzitou Santa Barbara v Kalifornii a (koncem 90. let) London School of Economics. Je autorem velké řady knižních publikací, jejichž počet se již bliží třicítce.

Giddens je teoretikem, jehož rozsáhlé dílo by bylo možné formálně rozčlenit do několika tematických okruhů; tyto okruhy se však namnoze vzájemně prostupují a pronikají. Jedná se o dílo, které zahrnuje kritickou analýzu myšlení vůdčích postav sociologie zakladatelské generace i autorů (ne pouze sociologů) soudobých. Zabývá se velkými tématy sociologie minulé i současné (tř́idní struktura, kapitalismus, modernita). Hlavně a především ale usiluje o nalezení a formulování nové koncepce, která by se mohla stát teoretickým a metodologickým východiskem bádání nejen v sociologii, ale v celé široké oblasti sociálních věd. V centru tohoto pokusu je vztah jednání a struktury, který se Giddens pokouší rešit prostřednictvím teorie strukturace.

Postav, s nimiž Giddens vstupuje v rámci své teoretické činnosti do kritického dialogu, je mnoho. Patři k nim např. T. Parsons, J. Habermas, M. Foucault, J. Derrida, L. Wittgenstein či M. Heidegger. Prominentní postavení mezi všemi zaujímá - zejména v počátcích Giddensovy vědecké kariéry - Karel Marx.

Giddensovo myšlení prošlo vývojem, v němž lze zaznamenat několik fází. V té první, náležejíci do šedesátých let, se kriticky zmocňuje dědictví klasikủ sociologického myšlení. Věnuje pozornost Marxovým analýzám kapitalistického systému a společenských tř̌id, Weberovým úvahám o politickém panství i Durkheimovým tématům sebevraždy a anomie. ${ }^{1)}$

\footnotetext{
1) Tato Giddensova orientace je do určité miry vysvětlitelná snahou zbavit se díky novému uchopení tradičních problémů závislosti na výkladových schématech, která jsou od dob klasikủ zavedená a stereotypně opakovaná; nacházet díky novému promýšlení klasických témat vlastní, originální řešení.
} 
Toto období, které kulminuje prací Capitalism and Modern Social Theory (1971), je charakteristické Giddensovou snahou uvést a zařadit do společenství zakladatelů sociologie vedle Maxe Webera a Emila Durkheima také Karla Marxe. Staví se tím odmítavě k známému Parsonsovu způsobu výkladu dějin sociologického myšlení, v němž je odlišena protosociologie generace předchůdců (Comte, Spencer, Marx) a vlastní vědecká sociologie (reprezentovaná Weberem, Durkheimem a Simmelem). Záměr rehabilitovat Marxủv myslitelský přínos přitom není pro Giddense jenom nějakým samoúčelem, nýbrž již od samého počátku je motivován úsilím o nalezení nového teoretického přístupu ke studiu „pokročilých“ společností. Navíc se zde zřetelně projevuje i zájem odrazit prevevahu americké sociologie a revitalizovat evropské tradice sociálněvědního myšleni /Giddens 1988b: 287/.

V druhé fázi, spadající do první poloviny sedmdesátých let, použil Giddens dosud vypracovaná východiska $\mathrm{k}$ analýze třídní struktury soudobých společností (The Class Structure of the Advanced Societies 1973) a elit. Paralelně s tím se zabýval kritickou analýzou dominujícího sociálněvědního pozitivismu, v jejímž rámci věnoval pozornost i takovým autorům jako Popper, Kuhn či Lakatos. Tato orientace jej nakonec přivedla k zájmu o interpretativní sociologii (fenomenologickou sociologii, etnometodologii a symbolický interakcionismus).

Pro třetí fázi je charakteristické to, že v ní Giddens dospívá $\mathrm{k}$ formulování teorie strukturace. Prvním významným dílem tohoto období jsou New Rules of Sociological Method (1976), v nichž Giddens nahrazuje Durkheimův „pozitivistický manifest“ $\mathrm{z}$ roku 1895 Les règles de la méthode sociologique souborem pravidel postpozitivistického vědeckého programu. ${ }^{2)}$ Uvedená kniha se pak stává Giddensovým východiskem pro úsilí o „,rekonstrukci“" základů kritické teorie společnosti trvající dodnes. Konkrétnější podobu nabývá toto směřování v Central Problems in Social Theory (1979), jistého stupně kodifikace pak dosahuje v The Constitution of Society (1984).

Od vydání této posledně jmenované knihy lze pak sledovat čtvrtou fázi, v níž se Giddens zabývá dalším rozpracováváním své teorie, vrací se k některým starým tématům (tř́idní strukturace), především ale otevírá témata nová - modernita (The Consequences of Modernity 1990), reflexivní modernizace /Beck, Giddens, Lash 1994/, globalizace, rizika, demokracie, lidské ,já“ a jeho identita (Modernity and SelfIdentity 1991).

Jako červená nit se Giddensovým dílem vine poukazování na Marxovu filozofii praxe. ${ }^{3)}$ Sociologii podle Giddense nelze chápat jako racionální, pozitivní a empiric-

\footnotetext{
2) Podle tohoto programu sociologie nemá co dělat s objektem, kterému by chyběly předpoklady, nýbrž s produkci a reprodukcí společnosti jakožto výsledku jednání jejích členủ. Tato jednání nejsou nikdy úplně svobodná, nebot podléhají restriktivním tlakủm. Společenské struktury produkuji ovšem nejen tyto tlaky, ale i možnosti. Strukturační procesy lze analyzovat na triádě významủ, norem a moci jako,,dualitu struktury". Každá sociologická analýza znamená ponor do životnich forem, který předpokládá dvojitou hermeneutiku danou vztahy mezi běžnými a vědeckými pojmy.

3) Přes všechny sympatie vüči strukturalismu a poststrukturalismu se Giddens postavil na odpor vůči ,francouzské módě“ nahrazovat Marxe Nietzschem a vydávat „vůli k moci“ za tajný motor dějin. Naopak Marx pro něj zůstává stěžejní postavou kritické teorie společnosti. V této souvislosti se hovoři o Giddensově "dekonstrukci" historického materialismu, jejíž smysl lze spatřovat v úsilí použít Marxe jistým způsobem proti němu samému. Tato dekonstrukce zavádí Giddense daleko za klasická témata historického materialismu a spolu s tím otevírá řadu marxisty tradičně opomíjených otázek.
} 
kou disciplínu, nýbrž je nutno ji od samého počátku chápat jako kritickou teorii společnosti, která zkoumá možnosti sociálního života jakožto „osvobozené praxe“.

\section{KRITIKA ORTODOXNÍHO KONSENZU}

Po druhé světové válce se v sociologii díky americkému vlivu prosazovala snaha spojit funkcionalistické modely s pozitivistickou filozofií vědy. Tím, jak ukazuje Richard Bernstein mělo dojít $\mathrm{k}$ akceleraci procesu vědeckého zrání sociální vědy /Bernstein 1979: 10\% Tato tendence byla provázena přijetím naturalismu (hovoři se dokonce o „prekérním" spojení tři ismů - pozitivismu, naturalismu a funkcionalismu), empirismu, deduktivně nomologického modelu (deduktivně konstruované vědění má směřovat $\mathrm{k}$ formulaci vědeckých zákonů) a akcentací hodnotově neutrálního přistupu (sociolog jako odborník na „sociálno" vytváří hodnotově neutrální instrumentální vědění).

Giddens své názory formuluje v polemice $\mathrm{s}$ trendem, který dominoval v americké sociologii od začátku padesátých do začátku sedmdesátých let a jehož reprezentanty byli především T. Parsons, R. K. Merton ${ }^{4)}$ a S. M. Lipset. Giddens tento trend označuje výrazem ortodoxní konsenzus a charakterizuje ho čtyřmi rysy : 1. z filozofického hlediska jde o naturalismus, 2. $\mathrm{z}$ metodologického hlediska o funkcionalismus, 3 . z hlediska sociální změny o evolucionismus, 4 . z historického hlediska v něm dominuje představa o základním transformativním vlivu industrialismu na společnost a její sociální strukturu /Giddens 1981: 88/.

1. Naturalismus je charakteristický postulátem jednoty přírodních a sociálních věd, založeným na předpokladu existence jedné společné reality a jednoho společného metodologického kánonu. Znamená to, že sociologie má sdílet podobnou epistemologickou koncepci jako přírodní vědy. (Řada autorů - nikoli ovšem Parsons sám - tento pozitivistický model vědy vypracovaný takovými autory jako Carnap, Hempel, Nagel príijala.)

2. Naturalismus a kopírování prírodních věd vedou $\mathrm{k}$ přijetí funkcionalistické metody a strukturně funkcionalistického způsobu explanace.

3. Z hlediska sociální změny byla konsenzuální teorie evolucionistická. I když byl evolucionismus překryt funkcionalismem, přetrvával, neztratil se. Např. u Parsonse (Societies: Evolutionary and Comparative Perspectives 1960) nacházíme jeho vlastní evoluční teorii. Přitom převládal dichotomický model změny. Giddens soudí, že Parsons použil Tönniesovu distinkci mezi Gemeinschaft a Gesellschaft jako základ svých vzorů proměnných, které mu posloužily k objasnění sociální změny.

\footnotetext{
4) Ideálním představitelem hlavního proudu americké sociologie byl především Robert K. Merton. Jeho koncept ,teorie středního dosahu“ umožnil vhodným zpủsobem prílibližit Parsonsovy teoretické názory konkrétním sociologickým problémům, aniž by sdílel Parsonsovu odstrašující pojmovou abstraktnost. Mertonovy přistupy inspirované analytickou filozofií dokázaly vtisknout funkcionalistické metodě sofistikovanou podobu. Ve vlastních analýzách, jako např. ve slavném konceptu anomie, ukázal tento autor jak navázat kontinuitu s klasickou sociologickou tradicí. Spolupráce s Lazarsfeldem mu navíc umožnila, aby své vlastní analýzy spojil s nejmodernějšími kvantitativními metodami. Díky tomuto jedinečnému spojení nejkomplexnější společenské teorie své doby (Parsons) s aplikací filozofických modelü (Carnap, Hempel, Nagel), vazbami na sociologické klasiky (Durkheim) a s využitím moderních kvantitativních metod (Lazarsfeld) popularizoval Merton svým dílem ortodoxní konsenzus neobyčejně úspěšně /Müller 1992: $156 /$
} 
4. Evolucionismus souvisí s teorií modernizace, $s$ představou, že industrialismus představuje základní transformativní vliv v moderní historii, nebot má všeobecně podobné důsledky pro cokoli ve společnosti. Marxismus je v důsledku toho považován za mrtvý, protože tř́ídní konflikt už v současném světě nehraje signifikantní roli; je překonán.

Nástup sedmdesátých let znamená ústup ortodoxního konsenzu. Důsledkem ovšem byla určitá fragmentace sociální teorie do množství paralelně existujících škol. Po určitou dobu se zdálo, že myšlení v sociální teorii zůstane kaleidoskopicky roztříštěné. Tato situace však podle Giddense pominula a úsilí o rekonstrukci sociální teorie přineslo určité plody. Giddens, jak sám uvádí, se na tomto úsilí o rekonstrukci sociální teorie podílel prrinejmenším dvěma knihami - New Rules of Sociological Method (1976), Central Problems in Social Theory (1979), jejichž cílem ovšem nemělo být vytvořit novou ortodoxii na místo staré.

V souvislosti s úsilím o rekonstrukci sociální teorie se začalo diskutovat o již zmíněných čtyřech problémech (o naturalismu, funkcionalismu, evolucionismu, industrialismu a modernizaci); pozornost byla věnována zejména problému naturalismu a modernizace.

$\mathrm{V}$ útoku proti naturalismu a pozitivismu se řada autorů orientovala na francouzskou a německou myšlenkovou tradici, která byla ve Spojených státech a ve Velké Británii poměrně neznámá. $\mathrm{V}$ této souvislosti byla také vyzvednuta hermeneutika, filozofie Lacanova, Foucaultova, Derridova, ale také fenomenologická sociologie (Schütz).

Pokud jde o problém modernizace, spojovaný namnoze s teorií industriální společnosti, vyslovil se $\mathrm{k}$ němu Giddens předevšim v knize The Class Structure of the Advanced Societies (1973).

\section{KRITIKA FUNKCIONALISMU}

Přestože Giddens považuje funkcionalismus za takříkajíc vyšlý z módy a překonaný, připouští, že na problémy, které do sociologie přinesli funkcionalisté, nelze jednoduše zapomenout (nehledě na to, že k zastáncům funkcionalismu náleží jiný významný soudobý sociolog - Niklas Luhmann).

Giddens se domnívá, že pojem funkce v sociologii použitelný není (podobně jako jiné technické termíny v sociálních vědách). Nicméně připouští, že mnozí, kteří kritizovali funkcionalismus, upadali do subjektivismu; jako např. fenomenologie.

V oblasti analýzy institucí a široké škály sociálních procesů je podle Giddense funkcionalismus silnější než fenomenologická sociologie. Dospívá proto k závěru, že chceme-li odstoupit od funkcionalismu, musíme jít na problém poněkud jinak než fenomenologická sociologie. Sám pro překonání funkcionalismu nabízí svůj teoretický koncept duality struktury.

Giddens definuje funkcionalismus jako typ doktríny, která soudí, že: a) Společnost nebo sociální systém má potřeby. b) Identifikace způsobů, ve kterých se vyrovnáváme s těmito potřebami, dává vysvětlení, proč jsou jednotlivé sociální procesy takové, jaké jsou.

Této doktríně Giddens oponuje z několika důvodů: 
1. Podobně jako sktrukturalismus představuje zbytek klamného dělení mezi statikou a dynamikou, mezi synchronicitou a diachronicitou.

2. Díky zdůrazňování systémových potřeb nejsou funkcionalističtí autoři schopni vidět lidské bytosti jako rozumné, uvažující aktéry, kteří jsou si z velké části vědomi toho, co dělají.

3. Systém nemá potřeby, potřeby maji lidé. Sociální systém nelze na základě funkcionalistického přistupu dostatečně popsat a vysvětlit /Giddens 1981: 90/.

Tyto závěry mají pro Giddense a pro jeho úsilí o rekonstrukci sociální teorie důležité implikace:

1. Jeden z nejdůležitějších bodů v Giddensově argumentaci je, že do centra sociální teorie se dostává časoprostorová relace, a to způsobem, který tu dřive chyběl. Diferenciace synchronicity a diachronicity, která je podle jeho názoru spojena s funkcionalismem, by měla být jednou pro vždy opuštěna.

Charakteristickým rysem synchronicko/diachronické distinkce je podle Giddense to, že při synchronickém zkoumání sociálního systému se z něho snímá něco jako fotografie, přesněji řečeno jakýsi druh „bezčasé momentky“ (timeless snapshot). Při této synchronické abstrakci od času, při tomto odhlédnutí od času je pak uvnitř sociálního systému identifikována sít funkcionálních vztahů.

Když naopak studujeme systém diachronicky, zkoumáme systém z hlediska času, respektive analyzujeme, jak se tyto vztahy mění v průběhu času.

Výsledkem podle Giddense je elementární, i když kruciální chyba: V důsledku toho, že je čas spojován pouze s diachronickým př́istupem, je identifikován nebo ztotožněn se sociální změnou /Giddens 1981: 91/. (V tomto smyslu se také obvykle konstatuje, že synchronická analýza nám dovoluje určit zdroje stability sociálních systémů, zatímco diachronická analýza je potřebná pro porozumění zdrojům změny v sociálních systémech.)

Chyba, o které Giddens hovoří, je způsobena odtržením oněch dvou pohledů. Jádro problému totiž spočivá $v$ tom, že čas je relevantní nejen při zkoumání změny, nýbrž i při zkoumání stability sociálního systému.

Čas je podle Giddense nezbytnou komponentou sociální stability. Stabilní sociální systém je systémem, který se vyvíji v čase. Je to systém, ve kterém existuje souvislost mezi tím, jak byly věci v minulosti, a tím jak jsou dnes. Existence sítě sociální vztahů uvnitř těchto systémů je neodlučitelná od jejich kontinuální reprodukce $\mathrm{v}$ čase. Omylem kritizovaného synchronického přistupu je předpoklad, že je možné vzít bezčasou momentku sociálního systému a odhalit jeho strukturu, jako lze udělat např. takovou momentku pokud jde o architekturu nějaké stavby. Chyba tedy vychází z mylného předpokladu, že sociální systém má takové strukturální náležitosti, které fungují nadčasově. Giddens naproti tomu zdůrazňuje časovou dimenzi sociální struktury.

2. Další Giddensova námitka se týká toho, že ve funkcionalistické teorii není adekvátně pochopeno lidské jednání ve smyslu, který musí zaujmout tento termín v rekonstruované sociální teorii /Giddens 1981: 91/.

I když se pojem jednání objevuje pod vlivem M. Webera i v Parsonsově koncepci, Giddens nepovažuje tento strukturálně funkcionalistický koncept jednání za dostatečný a adekvátní. Parsonsovi vytýká, že v jeho teorii neni postižena úloha lidských akté- 
rů jako bytostí, které svým jednáním produkují a reprodukují sociální instituce, a tím i celý sociální systém.

Giddens v tomto smyslu vyzvedá proti Parsonsovi Ervinga Goffmana, u něhož nalézá koncept jednajících lidských bytostí jako kvalifikovaných a znalých agentů, kteři využivají - $\mathrm{s}$ určitou rutinou - své vědění $\mathrm{k}$ produkci a reprodukci sociálních vazeb. To je podle Giddense koncept, který má v sociální teorii ústřední význam.

3. Poslední Giddensovou námitkou proti funkcionalismu je to, že sociální systém nemá potřeby, a nemá dokonce ani funkcionální nezbytnosti /Giddens 1981: 92/. Vẽtšina funkcionalistů považuje potřeby nebo požadavky za atributy sociálního systému a věři, že představují klíčovou roli v pochopení tohoto systému. Proti tomu Giddens namítá, že sociální systémy nemají potřeby, prrinejmenším ne ve smyslu, v jakém je mají individuální aktéri.

\section{AKTÉR̆I A JEDNÁNI}

Giddens podobně jako před ním i Parsons usiluje o položení teoretických základů sociálních věd. Parsonsův pokus založený na spojení „voluntaristické“ teorie jednání (reprezentující individuální svoubodu) a strukturně funkcionální teorie (reprezentující sociální řád) nepovažuje Giddens za zdařilý. Naopak soudí, že v něm zůstává nepřekonaná propast mezi jednáním a strukturou (jež se rýsuje např. mezi „unit act" a $A G I L$ schématem). Giddens se proto snaží spojit koncept jednání s představami o struktuře jiným způsobem. Jeho strategie spočívá ve vzájemném přiblížení obou pólů /Müller 1992: $168 /$.

Svým pojetím sociálního jednání se snaží akcentovat jeho objektivní stránky, zatímco na druhé straně dává pojem struktury do vztahu s procesy subjektivně zprostředkované strukturace. Giddensova strategie převádí dualismy na konstitutivní duality. Převládající pozitivismus nahrazuje představou dvojité hermeneutiky, dichotomii jednání a struktury zaměňuje dualitou struktury.

Sociální teorie se podle Giddense musí vypořádat především s otázkou lidských aktérů, jejich vědomím a jednáním, se strukturálními podmínkami a důsledky tohoto jednání a také $s$ institucionálními formami a kulturními symboly, které $\mathrm{z}$ toho vyplývají.

Sociologie je podle Giddensových představ disciplinou, která na takovém úsili participuje pouze dílčím způsobem a také v něm nezaujímá ani žádné privilegované postavení (její těžiště spočívá ve studiu ,pokročilých společností"). Sociální teorie v Giddensových představách funguje jako banka, od níž dostávají jednotlivé sociální vědy "peníze“, s nimiž ,pracuji“" a dosahuji „výsledkü“, které si opět u banky „,ukládaji“", aby tak samy ,jmění banky“ zvětšily. Sociální teorie a empiricky orientované sociální vědy se tedy nacházejí v neustálé výměně: sociální teorie by měla orientovat empirický výzkum, který naopak může být inspirací jejího dalšího rozvoje /Giddens 1988b: 287/.

Giddensovo pojetí jednání jako racionálně vysvětlitelného chování, které je reflexivně organizováno lidmi, je inspirováno řadou dobových myšlenkových proudů. Řadí se k nim filozofie vědy (Kuhn, Lakatos, Toulmin), lingvistická filozofie i interpretativní sociologie. Předmětem Giddensova zájmu se spolu s jednáním stává řeč a intersubjektivita $\mathrm{v}$ procesu produkce a reprodukce společenské reality. $\mathrm{Z}$ této perspektivy 
nahliží a diskutuje Schützovu fenomenologii, Garfinkelovu etnometodologii, Winchovu post-wittgensteinovskou filozofii a Habermasovu kritickou teorii. Nejde mu přitom ani o odhalení slabých a silných stránek, ani o snahu je co nejpřesněji interpretovat. Chápe je hlavně a především jako společnou odpověd na krizi teorie společnosti, jejímž projevem je zhroucení ortodoxního konsenzu.

Význam interpretativní sociologie spočíá pro Giddense v tom, že zdůrazňuje jazykovou zprostředkovanost a reflexivitu. Řeč jako médium a předpoklad interakce hraje klíčovou roli. Porozumění není pouze jednou z mnoha výzkumných metod, nýbrž je předpokladem každé společenské interakce /Giddens 1984b: 63/. Sociální výzkumníci stejně jako laičtí aktéři se uchylují ke stejné zásobě vědění a čerpají své poznatky ze stejných pramenů. Sociologické pojmy spočívají na předběžném laickém pochopení běžných pojmů. Podle Giddense podléhají sociologické analýzy dvojité hermeneutice: Př́stup k sociálnímu světu vede vždy nejprve přes významové rámce, znalosti a pojmy laických aktérů. Sociologie sice vytváŕí vlastní významové rámce, odborné vědomosti a vědecké pojmy, avšak ty si neustále komplexně zachovávají zpětnou vazbu na sociální svět.

V Giddensově pojetí je dvojitá hermeneutika chápána jako průnik dvou významových rámců, který je nezbytnou součástí sociální vědy: smysluplný sociální svět konstituovaný laickým aktérem na jedné straně a metajazyky tvořené společenskými vědci na straně druhé; neustálé klouzání (slippage) z jednoho rámce do druhého je součástí praxe sociálních věd /Petrusek 1990: 383/.

Giddensovo pojetí jednání (pojmy action a agency používá Giddens jako synonyma) se vyznačuje určitými rysy, které mohou z hlediska tradiční teorie jednání působit neobvykle. Jednání odkazuje ke konání - Agency refers to doing /Giddens 1984a: 10/, které je zpravidla zapojeno do kontinuálního proudu událostí sociálního světa nikoli jako reaktivní chování, nýbrž jako vědomé a reflexivně kontrolované konání aktérů. Giddens nezkoumá jednání jako diskrétní kreativní akt, nýbrž jako repetitivní praktiky zapojené do neustálého dění sociálního světa. Jednání představující časově řazené a prostorově lokalizované rekurzivní praktiky, které jsou schopny aktivně a významně zasahovat do sociálního dění, je v tomto pojetí spojené $\mathrm{s}$ již zmíněným pojmem praxe.

V odkazu na Goffmana a Garfinkela Giddens zdůrazňuje, že v současných komplexních společnostech by jedinci nemohli přežít bez své schopnosti rutinizace všedního dne. Proto většina jejich jednání vykazuje charakter opakování, které je také jedním $\mathrm{z}$ předpokladů důvěry ve stálost sociálního prostředí a pocitů ontologického bezpečí. Relevanci těchto procesů rutinizace jasně dokládají situace, v nichž jsou podkopány nebo otřeseny zaběhnuté formy obvyklého každodenního života /Giddens 1988a: 112/; tj. nejrůznějši kritické situace, v nichž je pocit důvěry a ontologického bezpečí zproblematizován.

Ve svém - interakcionismem inspirovaném - názoru poukazuje Giddens na stálou př́tomnost jiných lidí, s nimiž má aktér co do činění. Společně s Goffmanem to nazývá koprezencí. Koprezence je více než „prezence“, více než pouhá přitomnost; je určena blízkostí a důvěrností (důkladnou obeznámeností); bezprostřední kontakt (tváří $\mathrm{v}$ tvář) pro ni už není díky moderním komunikačním technologiím vůbec potřebný. 
Obraz, který Giddens vytváři o členech společnosti, v mnohém připomíná symbolický interakcionismus a fenomenologii. Giddensovy lidské bytosti jsou si vědomy samy sebe, jsou bdělé, aktivní a (sebe)reflexivní. Aktéři (jednající, agenti) jsou nadáni schopností chápat to, co činí, zatímco to čini“"/Giddens 1888a: 36/. Aktéři v průběhu socializace vyrůstají v relativně autonomní, dospělé lidi. Mají schopnost reflexivity a sebereflexivity.

Giddensův koncept jednání se drží představy kompetentního, vědomého aktéra, jehož popis je spojen se dvěma charakteristikami, označovanými jako knowledgeability a capability (v nich se zřetelně odráží vliv interpretativní sociologie).

Pojem knowledgeability souvisí s praktickým věděním, schopností reflexe, zásobou vědění a zkušeností jednotlivých aktérů. ${ }^{5)}$ Jednající podle Giddense zpravidla vědí, co činí a mohou $v$ případě potřeby o tomto svém konání také poskytnout kompetentní informaci. Capability jako schopnost jednání aktérů Giddens spojuje s konceptem moci /1984a: 15/ (kdo jedná, má automaticky určitou moc). Moc, která je vymezena jako vztah autonomie a závislosti mezi aktéry, v němž aktéři tvoři a reprodukují strukturní vlastnosti dominace, je integrálním elementem celého sociálního života.

V Giddensově pojmu aktéra a jednání je vyjádřen nárok na překonání dualismu mikroteorie a makroteorie. Fenomenologický přistup nabízí v tomto úsilí podle jeho názoru pomocnou, nikoli však dostačující perspektivu. Všichni kompetentní členové společnosti jsou podle Giddense v praktickém provádění sociálních aktivit velmi kvalifikovaní, v tomto smyslu jsou ,sociologickými experty“. Jejich vědění nezůstává vně nepřetržitého strukturování, nýbrž se do něj integrálně začleňuje. Tento přistup je rozhodující, máme-li se vyhnout chybám funkcionalismu a strukturalismu. Zároveň je ale důležité nepropadnout opačnému omylu hermeneutických či fenomenologických výkladů, které mají sklon k nazírání společnosti jako libovolně formovatelného výtvoru lidských subjektů /Giddens 1988a: 78/.

Lidé své jednání reflexivně monitorují, tzn. zaznamenávají, hodnotí, racionalizují a interpretují své vlastní jednání i jednání jiných. Tento proces probíhá na třech úrovních, na úrovni diskurzivního vědomí (racionalizace), na úrovní praktického vědomí (interpretace) a pod tlakem nevědomí. Nevědomí má podle Giddense v lidské činnosti nezanedbatelný význam (i když mají aktéři $\mathrm{k}$ dispozici značnou zásobu reflexe a zkušeností, má vědomé řizení jednání vždy jisté limity ze strany nevědomých motivů).

To, co působí mezi nevědomím a diskurzivním vědomím, je praktické vědomí; toto praktické vědomí (to, co aktér o podmínkách a důsledcích svého jednání a jednáních jiných sice ví, ale co není schopen diskurzivně vyjádřit) má v Giddensově koncepci ústřední význam /Petrusek 1990: 382/. Stálá kontrola vlastního jednání a sociálního kontextu vychází především $\mathrm{z}$ tohoto praktického vědomí, které se uplatňuje zejména v rutinním, běžném konání. Giddens tímto svým pojetím zdůrazňuje význam vědění a kompetence aktérů, které však nejsou absolutní, nebot at už je jejich vědomí jakkoli významné, přesto je omezeno a lidé často nemohou a nedokážou následky svého jednání odhadnout.

5) Pro tuto zásobu vědění a zkušeností používá Giddens také výraz mutual knowledge. 
Základní pojmy a teze své teorie rozvinul Giddens ve svém (patrně) hlavním díle The Constitution of Society (1984). Výstavba a intence této knihy je někdy přirovnávána k Habermasově Theorie des kommunikativen Handelns. Podobně jako Habermasovi jde i Giddensovi o reformulaci sociální teorie a o překonání jistých omezujících tradic. Přitom ovšem v žádném př́ipadě nestaví na ,zelené louce“", ale navazuje na řadu autorů; zvláště často jsou citováni (částečně souhlasně, částečně kriticky) zejména Goffman, dále Marx, Durkheim, Parsons, Foucault, Freud, Weber. Vedle nových myšlenek obsahuje Giddensovo dílo také četné neologismy (jazykové novotvary).

Kritika funkcionalismu přivedla Giddense $\mathrm{k}$ tomu, že ve svém díle navrhuje, aby byl nahrazen tím, co nazývá teorií strukturace. Tato teorie má řešit problém spojení jednání a struktury, a tím dosáhnout tak ř́kajíc temporalizaci struktur. Strukturaci jako proces odehrávajíci se $v$ čase a prostoru spojuje Giddens s konceptem duality struktury.

Podle teorie strukturace veškeré sociální jednání sestává ze sociálních praktik situovaných $\mathrm{v}$ čase a prostoru a organizovaných zběhlým a znalým způsobem aktéry. Tato lidská znalost nebo obeznámenost, se kterou lidé provádějí příslušné sociální praktiky, je vždy podmínkou jednání, ale je také zároveň důsledkem (nebo produktem) jednání.

Podstatný na Giddensově teorii strukturace je pokus překonat rozpor mezi teorií jednáni a mezi institucionální teorií. Tato snaha je dovršena konceptem duality struktury. Dualitou struktury se nazývá především to, že strukturální náležitosti (nebo součásti) sociálního systému jsou současně jak prostředkem (médiem), tak i výsledkem sociálního jednání /Giddens 1981: 92/.6)

Příkladem toho, co je současně předpokladem či prostředkem a zároveň také výsledkem sociálního jednání, je podle Giddense lidská řeč: Jednotlivé řečové akty mohou vznikat pouze $v$ rámci abstraktního souboru pravidel řeči, zároveň však tyto řečové akty stále znovu reprodukuji řeč jako abstraktní soubor pravidel. Vyslovím-li větu, je to určitý projev mého jednání, který zároveň jako nezáměrný důsledek udržuje při životě (reprodukuje) systém řeči /Müller 1992: 175/.

Proklamovaným cílem Giddensovy sociologie je spojení hledisek jednání a struktury, (nebo ještě jinak řečeno: překonání vzájemného rozporu a spojení mikroteorie a makroteorie). Struktura a jednání nepředstavují nějaké radikálně protikladné pojmy, nýbrž dvě dimenze téže věci. Giddensova teorie nahrazuje dualismus individua a společnosti dualitou jednání a struktury /Giddens 1988a: 215/, resp. dualitou struktury. ${ }^{7)}$

Giddens zastává názor, že společenské struktury jako takové nestojí proti jednáním individuálních aktérů, nýbrž do těchto jednání bezprostředně vstupují; a naopak, jednání aktérů vytvářejí struktury. To nazývá dualitou jednáni a struktury, nebo také jen

\footnotetext{
6) Velmi obecně by bylo možné konstatovat, že pojmem dualita struktury Giddens označuje produkci a reprodukci sociálního života.

7) Podle Archerové existuji čtyři virulentní dualismy /Archer 1982: 456/, které se táhnou teoretickou diskusí a se kterými se Giddens snaži vypořádat: dualismus mezi subjektem a objektem, mezi vysvětlováním a chápáním, mezi voluntarismem a determinismem, mezi statikou a dynamikou. Giddensova strategie spočivá v tom, že tyto dualismy převádí na duality.
} 
dualitou struktury. Tradiční dualismus, tedy ostrý protiklad jednání a struktury má být zaměněn konceptem duality. Na jednání a strukturu se nemá pohlížet jako na samostatné problémy, nýbrž se mají analyzovat ve svém vzájemném vztahu. Dualismus má být nahrazen dualitou.

Jednu ze základních tezí teorie strukturace Giddens formuluje takto: Pojmy struktura a jednání označují analyticky rozdílné momenty skutečnosti strukturovaných systémů jednání. Struktury samy neexistují vůbec jako samostatné fenomény prostorové a časové povahy, nýbrž pouze ve formě jednání a praktik lidských jedinců. Struktura se stává reálnou pouze v konkrétních realizacích praktického strukturování sociálních systémů /Giddens 1988a: 290/.

Jak konstatuje Hans-Peter Müller, je možné v zásadě rozlišit dvě tradice strukturálního myšlení. Ve funkcionalismu struktura většinou popisuje empirický vzorec sociálních vztahů:8) ve strukturalismu odkazuje na teoretický model, který jako kód nebo hlubinná struktura není přímo empiricky přístupný /Müller 1992: 173/.

Giddens se přiklání ke strukturalistickému pojetí. Představu struktury jako virtuálního vzorce transformativních vztahů př̀jímá Giddens od Léviho-Strausse a Derridy. $\mathrm{Z}$ tohoto pojetí pak také vychází Giddensův koncept strukturace, který se vztahuje na modality vztahů jednání a struktury.

Struktura jako skrytý virtuální vzorec se empiricky manifestuje ve společenské praxi. V tomto smyslu představují struktury institucionální, trvalé danosti, s nimiž jsou jedinci konfrontování, v nichž se pohybují, s nimiž žijí a s nimiž se musejí vyrovnávat.

Aktéri zahrnují struktury do svého jednání a struktury propůjčují tomuto jednání určitou jistotu a kontinuitu. Struktura na jedné straně omezuje jednání, ale na druhé straně ho také umožňuje. Bez struktur bychom byli neustále dezorientováni, a tudíž bezradní při zvládání našeho všedního dne. Na druhé straně vytyčují struktury našemu jednání hranice. ${ }^{9)}$

Jestliže v Giddensově pojetí predstavuje sociální systém takové uspořádání sociálních vztahů $v$ čase a prostoru, jaké je utvářeno a reprodukováno sociálními praktikami individuálních a kolektivních aktérů, pak pojem struktura označuje soubor pravidel a zdrojů, které lze ve virtuální rovině nahlížet jako vlastnosti sociálního systému.

Sociální systémy mají strukturu, kterou Giddens rozumí pravidla a zdroje, jež vstupují do produkce a reprodukce sociálních systémů. Pravidly, která představují jeden z prvků struktur, rozumí Giddens techniky a postupy, které nalézají své vyjádření především v praktickém vědomí /Giddens 1988a: 71/. Zdroje (ressource) chápe jako (pomocné) prostředky, které jsou dodatečně zapotřebí k pravidlủm, mají-li být vytvářeny a udržovány sociální systémy (produkce a reprodukce systémů).

\footnotetext{
${ }^{8)}$ Struktura jako „stabilní vzorec jednáni“" vstoupila do svazku s funkcionalismem nejprve jako deskriptivní, nikoli jako vysvětlující koncept. Těžiště explikace spočívalo v pojmu funkce. Spojení struktury a funkce bylo vypůjčeno $\mathrm{z}$ biologických modelů ( $\mathrm{z}$ analogií $\mathrm{s}$ organismy) a vedlo $\mathrm{k}$ již zmiňovanému naturalismu, v jehož pojetí byla struktura chápána jako „páteř“ nebo ,anatomie“ sociální formace, zatímco funkce reprezentovaly společenskou ,fyziologii“.

9) Tuto ambivalenci struktur ozřejmuje Giddens na přikladu osvojování jazyka: Každý jazyk omezuje myšlení a jednání, vymezuje mu určité hranice. Zároveň jazyk bezpochyby nesmírně rozšiřuje kognitivni a praktické schopnosti jedince /Giddens, 1988a: 224/. Z hlediska individuálního aktéra ovšem strukturální vlastnosti sociálních systémů zabíhaji tak dalece do prostoru a času, že se vymykají kontrole jakéhokoliv individuálního aktéra.
} 
Pravidla lze dělit na: a) normativní, jimž odpovídají legitimizační procesy, specifická práva a povinnosti a na úrovni sociálního systému systém sankcí, b) interpretativní, jimž odpovídají významy (significations), interpretativní schémata (jako součást disponibilního vědění) a na úrovni sociálního systému komunikace.

Zdroje se dělí na: a) alokativní, které zakládají dominaci vyplývající z možnosti manipulovat výsledky lidského ovládání přírody, b) autoritativní, které umožňují vykonávat moc na základě disponování nemateriálními prostředky, zejména prostřednictvím ovládání činností jiných lidí /Petrusek 1990: 381/. ${ }^{10)}$ Jinak řečeno: Alokativní zdroje se vztahují $\mathrm{k}$ panství nad př́rodou a zahrnují materiální vlastnosti prostředí (suroviny), produktivní a reproduktivní síly (technologie) a zboží vyrobené pomocí surovin a technologie. Autoritativní zdroje se týkají kontroly společnosti (panství nad lidmi) a zahrnují organizaci sociálního prostoru a sociálního času, produkci a reprodukci lidského těla a organizaci životních šancí lidí /Müller 1992: 182/

Toto členění se stává pro Giddense východiskem jeho teorie institucí a v tomto smyslu také rozeznává čtyři institucionální ráay: symbolický, politický, ekonomický a legální.

Giddensova teorie strukturace pracuje s řadou pojmů, jejichž vzájemné vztahy přibližuje schéma nazvané Úrovně Giddensovy strukturačni analýzy. Z tohoto schématu je zřejmé, že každá interakce aktérů sociálního života se skládá ze tř́ komponent ${ }^{11)}$ - komunikace, moci a sankcí, spojených na strukturální úrovni s procesy signifikance, dominace a legitimace. Jednotlivé aspekty interakce - komunikace smyslu a významu, užití moci, morální vztahy a sankce - tak mají svůj zrcadlový korelát v aspektech struktury, představovaných interpretativními pravidly, zdroji a normativnivnimi pravidly. Na úrovni individuálního jednání odpovídají pravidlům a zdrojům pojmy knowledgeability a capability.

\section{Úrovně Giddensovy strukturačni analýzy}

\begin{tabular}{|l|l|l|l|l|}
\hline Individuální jednání & Charakter interakce & Sturktura & Pravidla a zdroje 2 i2) & Institucionální řády \\
\hline knowledgebility & $\begin{array}{l}\text { komunikace } \\
\text { smyslu a } \\
\text { významu }\end{array}$ & signifikance & $\begin{array}{l}\text { interpretativní } \\
\text { pravidla }\end{array}$ & symbolický \\
\hline capability & užití moci & dominace & $\begin{array}{l}\text { autoritativní } \\
\text { zdroje }\end{array}$ & politický \\
\cline { 3 - 5 } knowledgebility & $\begin{array}{l}\text { morální vztahy } \\
\text { a sankce }\end{array}$ & legitimace & normativní pravidla & právní zdroje \\
\hline
\end{tabular}

10) Giddens pohliží na marxismus jako na prototyp teorie koncentrované na problém alokativních zdrojů. Weberovo dílo o politickém panství, státu a byrokracii představuje naopak prototyp teorie zdủrazňující autoritativní zdroje.

11) Protože tyto kompenenty vytvářejí v konkrétnich projevech interakce složitou splet vztahủ, lze je od sebe oddělit pouze analyticky.

12) Schéma názorně dokládá korespondenci mezi pravidly, zdroji a institucionálními rády; může však navozovat určitou zjednodušující představu, kterou je nutno korigovat poukazem na vzájemné provázanosti 
Nejzákladnější problém sociologie představuje pro Giddense problém řádu; ${ }^{13)}$ pojímá jej jako problém organizace společnosti v čase a prostoru /Giddens 1988a:161/. Sociální systém představuje takové uspořádání sociálních vztahů v prostoru a v čase, které je neustále utvářeno, reprodukováno a měněno sociálními praktikami aktérů.

Jak pro jednání, tak pro struktury je klíčovým aspekt času a prostoru. Ty nepředstavují $v$ žádném případě pouze nějaké okrajové nebo vnější faktory, nýbrž jsou základními podmínkami. Giddens se $\mathrm{v}$ této oblasti orientuje především za pomoci analýz norského geografa Hägerstranda a čerpá opět z Goffmana.

Význam Goffmanova díla spočívá podle Giddense $\mathrm{v}$ jeho zkoumání prostorového a časového řádu sociálního jednání. Goffman je jedním z mála sociologů, kteři pojednávají vztahy času a prostoru jako fundamentální vztahy pro produkci a reprodukci společenského života, místo aby je chápali jako hranice sociálního jednání, které by mohly být klidně přenechány specialistům - geografům a historikům /Giddens 1988a: 90/.

Giddens rozlišuje tři formy prostorovosti:

1. regiony (v Goffmanově smyslu averzní a reverzní regiony; např. v restauraci averzní region lokálu a reverzní region kuchyně);

2. prostorové aspekty těla, pohyb v čase a prostoru;

3. místní danosti institucí a konvencí (např. konvence, že manželství jsou uzavírána na radnici nebo v kostele).

Vnitřní diferencování společností se obráží v regionalizaci. Každodenní, rutinizovaná jednání (spánek, jídlo, práce atd.) se odehrávajî v různých prostorech.

Aspekty času a prostoru se $\mathrm{v}$ současných společnostech mísí, protože pro různé aktivity jsou typické a zažité určité doby a určitá místa. (Např. domy jsou regionalizovány do poschodí, chodeb a místností. Různé místnosti domu jsou jak v prostoru, tak $\mathrm{v}$ čase rozděleny různým způsobem do zón; třeba tak, že určité místnosti jsou používány většinou jen v denních hodinách, a jiné zase v noci /Giddens 1988a: 171/.)

Podle Giddense mủže sociologická teorie vysvětlit procesy, jaké představuje např. urbanizace $\mathrm{v}$ moderních společnostech jen tehdy, pokud bere $\mathrm{v}$ potaz čas a prostor. Všechny společnosti se skládají z časových a prostorových zón: každá koordinace jed-

jednotlivých aspektů struktury: Symbolický řád, způsoby diskurzu a vzorce komunikace jsou produkovány a reprodukovány na základě interpretativních a normativních pravidel a prostřednictvím obou typů zdrojů, alokativních a autoritativních. Politické instituce závisí především na autoritativních zdrojích a obou typech pravidel. Ekonomické instituce jsou produkovány a reprodukovány alokativními zdroji a oběma typy pravidel. Právní instituce jsou založeny na užití normativních pravidel spolu s autoritativními zdroji a pouze sekundárně souvisejí s alokativními zdroji a interpretativními pravidly /Petrusek 1990: 383 /

13) I když Giddens podobně jako Parsons vyzvedá jako klíčový problém sociálního rádu, volí ve srovnání $s$ ním jinou konceptualizaci a jiné řešeni. V Parsonsově případě jde o spojení individuální svobody a společenského řádu, kterého se dosahuje předevšim prostřednictvím institucionalizovaných hodnot a jejich interiorizace ze strany aktérů. Giddens vycházející z konceptu duality struktury se orientuje na problém prostoru a času. V Parsonsově teorii odkazuje systémová integrace na koordinaci a mediální řizení institucí a jejich funkcionálních příspěvkủ, zatímco sociální integrace je zaměřena na socializačně zprostředkovanou integraci jedince do společnosti. V Giddensově pojetí odkazuje systémová integrace na časoprostorově distancovanou formu integrace a sociální integrace na koordinaci v koprezentnich situacích. Systémová integrace se vztahuje na reciprocitu skupin nebo kolektivů, sociální integrace na reciprocitu aktérů. 
nání v prostoru spoluzahrnuje čas. Možnosti aktérů pohybovat se v prostoru a čase jsou omezeny nejrůznějšimi faktory.

Pro moderní společnosti je charakteristická velká rozpínavost vzhledem k prostoru. Zatímco v předmoderních společnostech znamenala velká distance (mnoho prostoru) mezi dvěma místy také mnoho času, je dnes tato jednoduchá úměra porušena. $\mathrm{V}$ současných společnostech je pro nemálo lidí mnohem jednodušši spíše se dostat na jiný kontinent než na odlehlé místo vlastní země. Rozlišování mezi centrem a periferií (které je známé $\mathrm{z}$ analýzy světové společnosti a $\mathrm{z}$ výzkumů nerovnosti) se tak dostává do zcela nové polohy /Treibel 1993: 246/.

Podle teorie strukturace zahrnuje každý moment sociální reprodukce tř̌i protínající se, vzájemně se pronikající úrovně času: 1 . je to temporalita bezprostřední zkušenosti, tzn. kontinuálního plynutí každodenního života - to, co Schütz v návaznosti na Bergsona nazývá trváním - durée, 2. temporalita pobytu (Dasein), tzn. života a jeho cyklů, 3. je to longue durée (Braudelův termín) - „dlouhé trvání institucionálního času, spojené s vývojem a reprodukcí sociálních institucí /Giddens 1981: 93/.

Institucemi Gidens rozumí systémy interakcí, které trvají v čase „dlouhého trváni““ a které mají možnost distribuovat lidi v prostoru.

V souladu s teorémem duality struktur zahrnuje každý moment sociální interakce „dlouhé trvání“ institucionálního času. Např. nejtriviálnější výměna slov zahrnuje mluvčí do long-term history řeči, ve které byla tato slova zformována, a současně i do její pokračujicí reprodukce. V této souvislosti Giddens kritizuje fenomenologicky orientované analýzy, které se obvykle zabývají „schützovským durée ", ale neberou na zretel „Braudelovo durée". Giddens navíc odmítá myšlenku, že by v teorii strukturace měla mít nějaká forma „,durée“ logické prvenství oproti jiné.

„Dlouhé trváni““ institucionálního času nás přivádí $\mathrm{k}$ problematice evoluce. Evoluční teorie se týká času, a to v dvojím smyslu: jednak plynutí času v „dlouhém trvání", jednak psaní o čase ve smyslu interpretace historie. V konsenzuální teorii převládal pohled, který vymezoval vztah mezi sociologií a historii dosti jasně: historici produkují surový materiál, který sociologové zobecňují. Sociologie se má zabývat odhalováním zákonitostí a generalizací, které mají týž logický status jako zákony v přirodních vědách. Takové zákony abstrahují od času a místa a jsou kromě limitujících podmínek použitelné na všechny historické periody. Historie se pak zabývá obsahem, který mủže být v duchu těchto zákonů uspořádán a organizován.

Giddens nevěří, že taková jasná dělící čára mezi sociologií a historií existuje, a navíc se domnívá, že sociologii nelze budovat podle modelu prírodních věd. Tím nechce říci, že neexistují sociologické zákony nebo generalizace, konstatuje pouze, že tyto zákony nemaji identickou logickou formu se zákony přírodních věd a nemají také jejich univerzální charakter. Jsou to zákony historické a přičinné vztahy, které vyjadřují, jsou proměnlivé ve světle lidského vědění - včetně toho druhu vědění, které produkují sociologové /Giddens 1981: 93/.

Giddens zamítá každou formu evolučních idejí (zájem o ně se obnovil v důsledku Parsonsova vlivu), zvlăště pak vystupuje proti tomu typu dichotomických koncepcí, které byly populární v 19. století. Evoluční představy považuje v sociologii za škodlivé. Namísto nich razí pojem epizody a hovoří o tzv. epizodickém vývoji. Těmito výra- 
zy charakterizuje transformační procesy, ohraničené určitými časo-prostorovými rozhraními (time-space edges). Vytváří tím možnost hovořit o simultánnosti existence různých typů společností (např. industriální kapitalismus existoval a existuje ve spojení s různými jinými typy společností), které procházejí epizodickými přechody /Giddens 1981: 95/.

Giddensova dekonstrukce historického materialismu zde podle Hanse-Petera Müllera směřuje $\mathrm{k}$ úsili nahradit Marxovu dialektiku výrobních sil a výrobních vztahů logikou překonávání časoprostoru, která vede $\mathrm{k}$ neevolucionistickému pojetí společenských formací /Müller 1982: 190-191/. Dějiny podle Giddense nevykazuji kontinuální průběh a kapitalismus nepředstavuje jejich vyvrcholeni. Mají naopak kontingentní povahu a epizodický průběh; jejich scénáře vytváři časoprostorová koexistence různých typů společenských formací.

\section{Literatura}

ARCHER, M. S.: Morphogenesis vs. Structuration. In: British Journal of Sociology 33, 1982, s. 455-483. Beck, U., Giddens, A., Lash, S.: Reflexive Modernization: Politics, Tradition and Aesthetics in the Modern Social Order. Polity Press, Cambridge 1994.

BERNSTEIN, R. J.: Restrukturierung der Gesellschaftstheorie. Suhrkamp, Frankfurt/M. 1979.

GidDENS, A.: Capitalism and Modern Social Theory: The Analysis of the Writings of Marx, Durkheim and Max Weber. Cambridge University Press, Cambridge 1971.

GIDDENS, A.: The Class Structure of the Advanced Societies. Hutchinson, London 1973.

GidDENS, A.: New Rules of Sociological Method. Hutchinson, London 1976.

GidDnes, A.: Central Problems in Social Theory: Action, Structure and Contradiction in Social Analysis. Macmillan, London 1979.

GIDDENS, A.: Time and Space in Social Theory. In: Lebenswelt und soziale Probleme, hrsg. von Matthes, J., Campus Verlag GmbH, Frankfurt/Main 1981, s. 88 - 97.

GIDDENS, A.: The Constitution of Society: Outline of the Theory of Structuration. University of California Press, Berkeley - Los Angeles 1984a.

GIDDENS, A.: Interpretative Soziologie: Eine kritische Einführung. Campus, Frankfurt/M. - New York 1984 b. GidDENS, A: Die Konstitution der Gesellschaft. Grundzüge einer Theorie der Strukturierung. Campus, Frankfurt/M. - New York 1988a.

GiddENS, A.: Die „Theorie der Strukturierung“. Ein Interview mit Anthony Giddens von Bernd Kießling. In: Zeitschrift für Soziologie 1988 b, s. 286-295.

GidDENS, A.: Důsledky modernity. Sociologické nakladatelství, Praha 1998.

MULLER, H.-P.: Sozialstruktur und Lebensstile: Der neuere theoretische Diskurs über soziale Ungleichheit. Suhrkamp, Frankfurt/M. 1992.

PETRUSEK, M.: Spor o teorii strukturace Anthonyho Giddense v západní sociologii. In: Sociologický časopis $26,5 / 1990$, s. $375-391$.

PETRUSEK, M.: Anthony Giddens: Teoretik strukturace a modernity. Doslov ke knize: Giddens, A.: Důsledky modernity. Sociologické nakladatelství, Praha 1998, s. 159 - 195.

TreibeL, A.: Einführung in soziologische Theorien der Gegenwart. Leske + Budrich, Opladen 1993. 
The Starting Points of Giddens' Approach

to the Reconstruction of Social Theory

\section{Summary}

Anthony Giddens is a social theoriest whose extensive works present a critical analysis of the thought of leading founding fathers of sociology and of contemporary authors (and not only sociologists). He is concerned with the great themes of sociology past and present (class structure, capitalism, modernity). Above all, however, he has striven to find and formulate a new conception that could provide the theoretical-methodological starting point for research not only in sociology but in the whole range of social sciences. At the centre of this enterprise is the relationship between action and structure, which Giddens tries to solve using the theory of structuration.

According to the theory of structuration all social action is formed out of social practices situated in time and space and organized by the actors in an expert and knowledgeable way. The human knowledge or familiarity with which people carry out the appropriate social practices is always both the condition of action and at the same time the result (or product) of action. Giddens' theory of structuration is an attempt to overcome the contradiction between the theory of action and institutional theory. It culminates in the concept of duality of structure, which is to be understood primarily as the idea that the structural elements of the social system are at the same time a means (medium) and result of social action. 